\title{
Effect of temperature variability on predatory mite, Hemicheyletia congensis (Cunliffe) (Acari: Actinidida: Cheyletidae) feeding on Petrobia tritici Kandeel, El- Naggar \& Mohamed (Acari: Tetranychidae)
}

\author{
Amira E. Mesbah
} Cotton and Field Crops Acarology Department, Plant Protection Research Institute, A.R.C., Dokki, Giza, Egypt. E-
mail, Ameramites@yahoo.com

\begin{abstract}
Temperature is a vital environmental factor affecting the biological control agent, Hemicheyletia congensis (Cunliffe) (Acari: Cheyletidae). Biological aspects and life table parameters of $H$. congensis were studied under laboratory conditions at 20, 25 and $30^{\circ} \mathrm{C}$ and $65 \%$ R.H. It was fed on Petrobia tritici Kandeel, El- Naggar \& Mohamed (Acari: Tetranychidae), a pest of wheat. Developmental durations of different stages decreased as temperature increased and were fitted to the linear regression model with $\mathrm{R}^{2}$ values ranged between 0.82 to 0.99 (mean 0.94) and zero developmental time between 5 and $12^{\circ} \mathrm{C}$ (mean $8.74^{\circ} \mathrm{C}$ ). The maximum oviposition rate of 98.6 eggs/female was at $25^{\circ} \mathrm{C}$ followed by 86.2 at $30^{\circ} \mathrm{C}$ and 68.5 at $20^{\circ} \mathrm{C}$. Life table parameters showed highest value for the Net reproductive rate $\left(R_{o}\right)$ as 62.84 at $25^{\circ} \mathrm{C}$. Highest intrinsic rate of natural increase $\left(r_{m}\right)$ was reached as 0.220 at $30^{\circ} \mathrm{C}$ while lower $r_{m}$ values as 0.109 and 0.165 at 20 and $25^{\circ} \mathrm{C}$, respectively. The survival rate from egg to adult was $0.75,0.90$ and 0.80 , at tested temperatures, respectively. Sex ratios were $0.70,0.75$ and 0.70 respectively. Time for population doubling was determined as $6.35,4.20$ and 3.15 days, respectively. $H$. congensis had the highest predation capacity at $25^{\circ} \mathrm{C}$ as 419.3 prey immatures per females and 299.7 for males, during predators' life span. The number of prey consumed during predator total immatures averaged 50, 104.5 and 71 prey for predator female and 41.7, 104.2 and 62.1 prey for predator male, respectively. Results indicated the possibility of mass rearing of $H$. congensis at $25^{\circ} \mathrm{C}$ for further studies.
\end{abstract}

Key words: wheat, cheyletid, mite, biology, life tables, Tetranychidae.

\section{INTRODUCTION}

Wheat, Triticum aestivum $\mathrm{L}$. is the main stable food crop in Egypt and source of energy (carbohydrate) and contains high amounts of nutrients such as proteins, fiber, lipids, vitamins, minerals, and phytochemicals which may contribute to a healthy diet (Shewry and Hey 2015).

Various arthropods factors lead to serious damage to wheat crops throughout their life stages. Among these factors, mites of the family Tetranychidae which known as spider mites; pests in agricultural and forestry ecosystems, can be found on many field crop, fruit trees, vegetables, ornamental plants and also in large numbers in wheat crops (Royer 2009). These mites are more likely to cause injury in wheat that is stressed from lack of moisture or nutrients. From those, Brown wheat mite, Petrobia tritici Kandeel; El- Naggar and Mohamed (Acari: Tetranychidae) that can build up large populations and infest wheat through feeding on leaves by piercing plant cells from wheat leaf which results in leaf yellowing and in wilting and dying of plants and capable of reducing wheat yields and this species described from wheat, barley, sorghum, sugar beet, clover, lupine, garlic and onion, Sharkeia Governorate, Egypt (Kandeel et al. 2007).
Brown wheat mites usually have different generations per season. It is considered sap-sucking pest of cereals that is most active in dry warm weather (Omar and Mesbah 2015)

Predaceous mites of the family Cheyletidae showed a remarkable variability in their predation habits, including acaridida mites as well as, phytophagous mites such as spider and tenuipalpid mites, (Hassan et al. 2014; Carrillo et al. 2012; Mesbah and Omar 2014).

Listed cheyletid mites published by the genus Hemicheyletia have three subgenra, Cheletominus, Hemicheyletia and Philippicheyla (Gerson et al. 1999).

The most recent review of cheyletid mites in Egypt was published by Negm and Mesbah (2014) since Zaher (1986). They reported that the family Cheyletidae (Acariformes: Actinidida) contains twenty-seven nominal species within 15 genera. They indicated that this area is rich in cheyletid species. Further and extensive studies are recommended for other cheyletid genera and species which inhabit different environments.

Cheletomorpha lepidopterorum (Shaw) (Acari: Cheyletidae) was reared on immature stages of different mite diets belonging to suborder Astigmata (Tyrophagus putrecentiae (Schrank), Lepidoglyphus destructor (Schrank), Rhizoglyphus echinopus (Fumouze and Robin) and Caloglyphus betae Attiah) at different 
temperatures $\left(20,25\right.$ and $\left.30^{\circ} \mathrm{C}\right)$ and $(70-80$ \%R.H.) (Yassin et al. 2008). Also $C$. lepidopterorum was reared on nymphal stages of acarid mite, Tyrphagus putrescentiae at three different temperatures $\left(15,25\right.$ and $\left.35^{\circ} \mathrm{C}\right)$ and $65 \pm$ $5 \%$ R.H. in the laboratory (El-Naggar et al. 2006). The tested temperatures showed a noticeable effect on the individually development of predator and the temperature $15^{\circ} \mathrm{C}$ was the suitable for predator fertility and food consumption (El-Naggar et al. 2006 and ElEnany et al. 1992).

Biological aspects of C. lepidopterorumn were determined on three different immature stages of two acarid mites (the seed wheat mite, Goheria wahabeii El-Naggar, Taha \& Hoda and the storage grain mite, Blomia tropicalis Bronswijk at $20^{\circ} \mathrm{C}$ and $60 \%$ R.H in the laboratory (Mesbah et al. 2017).

The relationship between temperature and the population growth rate of Cheyletus malaccensis Oudemans was studied as useful for predicting its population dynamics. Age-stage, two-sex life tables of the predator, $C$. malaccensis, reared on Acarus siro were conducted under laboratory conditions at 22, 24, 28,30 , and $32^{\circ} \mathrm{C}$, and $75 \%$ relative humidity (Sun et al. 2020).

The present study aims to evaluate the ability of the predatory mite, Hemicheyletia congensis to feed and development on the brown white mite $P$. tritici as a biocontrol agent under laboratory conditions.

\section{MATERIAL AND METHODS}

\section{Stock colonies of Hemicheyletia congensis:-}

The individuals of the predatory mite, Hemicheyletia congensis were maintained for three months before the beginning of the experiment feeding on astigmatid mite stages, Lepidoglyphus destructor. It was mass reproduced on a mix of yeast granules-wheat germ-bran as a food source. L. destructor taken for rearing on cages filled with a substrate of a mixture of (Cement: Clay: Charcoal) with ratio of (1:2:7) filled on the bottom of cages to depth of $0.5 \mathrm{~cm}$. Its bottom was scratched by using a needle to make convexo-concaved areas used as shelters and was suitable sites for predator mite rearing and laying eggs (Zaher et al. 1981and Hassan et al. 2014). Water drops was added when needed .The experiment was monitored twice daily.
Pure culture of the tetranychid mite, Petrobia tritici: The Brown wheat mite reared at $25^{\circ} \mathrm{C}$ on fresh mulberry leaves, Morus alba L. Each leaf was put on a pad of cotton saturated with water as a source of moisture and to prevent mite escaping.

Reproduction of $\boldsymbol{H}$. congensis on $\boldsymbol{P}$. tritici: Pure culture was initiated by transferring males and females of mite species using a fine hair brush to fresh discs of Mulberry leaves in Petri dishes $(10 \mathrm{~cm}$ in diameter). Each leaf was put on a pad of cotton saturated with water as a source of moisture and to prevent mite escaping. The rearing stocks were conducted in an incubator at $25 \pm 2{ }^{\circ} \mathrm{C}$ and $70 \pm 5 \%$ relative humidity. Immature stages of phytophagous mite were supplied to predator mite when needed and Biological aspects recorded daily.

Statistical analysis: The relationship between temperature and mean developmental rate of each stage under teste temperatures was determined using linear regression $(\mathrm{Y}=\mathrm{a} \pm \mathrm{bx}$, where: $\mathrm{a}=$ Intercept, $b=$ slope of temperature). The lower developmental threshold $\mathrm{t} 0=-\mathrm{a} / \mathrm{b}\left({ }^{\circ} \mathrm{C}\right)$ and thermal units $\mathrm{K}=1 / \mathrm{b}$ (in degree day units (DDUs)), where: to is developmental threshold ${ }^{\circ} \mathrm{C}$; $\mathrm{b}$ is the developmental rate line slope and $\mathrm{K}$ is the developmental heat constant (DDUs) were determined. Life table parameters were done according to Birch (1948) using the Life48, BASIC, Computer Program (Abou-Setta et al. 1986). Food consumption and predation capacity were compared at the three temperatures using one way analysis of variance (ANOVA) using SAS statistical software (SAS Institute, 2003).

\section{RESULTS AND DISCUSSION}

Mating, egg deposition and hatching: Mating is necessary for egg depositing. It was noticed that Hemicheyletia congensis usually present around its prey, Petrobia tritici. When touched it, rapidly move backward and went back to attack it again. The predator seized firmly the prey with the aid of its raptorial pulps and sucked its contents by its chelicerae from any part of the body. The new hatched larvae were colorless; changed into yellow, then orange color beings appear at the end of the larval stage, becoming more intense at each succeeding stage. The color of emerging nymphs is usually orange, gradually becomes darker after feeding on $P$. tritici. Before proceeding to the following stage, active immature mites usually enter a quiescent (rest) 
stage. The mite tries to strip itself from the old skin by twisting movements and subsequently pull out the forelegs and anterior parts of the body from the old skin. Afterwards, it crawls forward trying to pull out the posterior part from the exuviate. Previous results clarified that $H$. congensis females and males were found to pass through one larval and two nymphal stages (protonymph and deutonymph) before reaching the adult stage when reared on $P$. tritici at different temperatures (Mahagoub et al. 2017).

Biological aspects: Mean obtained biological aspects of this predator are presented in Table (1). Increasing temperature showed a remarkable

Table 1. Mean biological aspects of H Hemicheyletia congensis reared on Petrobia tritici at different temperatures.

\begin{tabular}{|c|c|c|}
\hline \multirow{2}{*}{ Biological aspects } & \multicolumn{2}{|r|}{ Female } \\
\hline & $20^{\circ} \mathrm{C}$ & $25^{\circ} \mathrm{C}$ \\
\hline Egg & 5.60 & 4.65 \\
\hline Active larva & 4.80 & 3.60 \\
\hline Quiescent larva & 1.70 & 1.30 \\
\hline Active protonymph & 4.40 & 3.20 \\
\hline Quiescent Protonymph & 1.15 & 1.25 \\
\hline Active deutonymph & 3.80 & 3.35 \\
\hline Quiescent deutonymph & 1.50 & 0.73 \\
\hline Immature & 17.35 & 13.43 \\
\hline life cycle & 22.95 & 18.08 \\
\hline Generation & 26.75 & 20.78 \\
\hline Preoviposition & 3.80 & 2.70 \\
\hline Oviposition & 20.80 & 17.40 \\
\hline Postoviposition & 4.15 & 3.40 \\
\hline Longevity & 28.75 & 23.50 \\
\hline Fecundity & 68.50 & 98.60 \\
\hline Daily rate & 3.30 & 5.72 \\
\hline Life span & 51.70 & 41.58 \\
\hline $\begin{array}{l}\text { Linear regression } \\
\text { developmental rates for } \\
P \text {. tritici at different ter } \\
\text { in Table }(2) \text {. Increasing } \\
30^{\circ} \mathrm{C} \text { cased significa } \\
\text { biological aspects of th } \\
\text { value of } 0.94 \text { and rang } \\
\text { developmental thresholc } \\
\text { and } 9.33^{\circ} \mathrm{C} \text { for female } \\
\text { Required degree days } \\
\text { determined as } 333.3 \mathrm{deg}\end{array}$ & $\begin{array}{l}\text { lysis } \\
\text { congens } \\
\text { ratures a } \\
\text { aperature } \\
\text { reducti } \\
\text { edator w } \\
\text { f } 0.82 \\
\text { s determ } \\
\text { male, } \\
\text { o both }\end{array}$ & $\begin{array}{l}\text { es for } \\
\text { eared on } \\
\text { resented } \\
\text { m } 20 \text { to } \\
\text { on all } \\
\text { mean } \mathrm{R}^{2} \\
\text { 99. The } \\
\text { as } 12.0 \\
\text { ectively. } \\
\text { es were }\end{array}$ \\
\hline
\end{tabular}

\section{Life table parameters}

Life table parameters of $H$. congensis reared on $P$. tritici are presented in Table (3) and illustrated in Figure (1). Life table parameters were estimated at tested temperatures as: mean effect on all predator stages. Incubation periods were 5.6, 4.65 and 3.05 days for female at 20, 25 and $30^{\circ} \mathrm{C}$, respectively. Life cycle $21.75,17.97$ and 12.23 days for male and 22.95, 18.08 and 12.0 days for female when the predatory mite, $H$. congensis reared on the three tested temperatures, respectively. Adult longevity lasted 28.75, 23.5 and 19.0 days for female and 21.1, 16.5 and 14.4 days for male, respectively. Females' fecundity averaged of 98.6 eggs at $25^{\circ} \mathrm{C}$ followed by 86.2 eggs at $30^{\circ} \mathrm{C}$ and 68.5 eggs at $20^{\circ} \mathrm{C}$. Thus, $25^{\circ} \mathrm{C}$ was considered the suitable temperature for rearing of $H$. congensis on $P$. tritici. 
$25^{\circ} \mathrm{C}$ (day 26: $5.55 \mathrm{eggs} / \mathrm{Q} / \mathrm{day}$, while these values at $30^{\circ} \mathrm{C}$ was (day 19: $5.25 \mathrm{eggs} / q /$ day), followed by (day 30: $3.36 \mathrm{eggs} /$ + $/$ day) at $25^{\circ} \mathrm{C}$. After that, egg production decreased gradually. The highest survival rate of females was $0.9 \%$ at $25^{\circ} \mathrm{C}$, while lowest value was $65.0 \%$ at $25^{\circ} \mathrm{C}$.

Table 2. linear regression analysis values for developmental rates for Hemicheyletia congensis reared on Petrobia tritici under laboratory conditions at different temperatures.

\begin{tabular}{lcccccc}
\hline Stage & Variety & $\mathrm{a}$ & $\mathrm{b}$ & $\mathrm{t}_{0}$ & $\mathrm{~K}$ & $\mathrm{R}^{2}$ \\
\hline \multirow{2}{*}{ Egg } & Female & -0.132 & 0.014 & 9.43 & 71.43 & 0.91 \\
\cline { 2 - 7 } & Male & -0.098 & 0.013 & 7.53 & 76.92 & 0.82 \\
\hline \multirow{2}{*}{ Larva } & Female & -0.183 & 0.016 & 11.44 & 62.50 & 0.95 \\
\cline { 2 - 7 } & Male & -0.064 & 0.01 & 6.40 & 100.00 & 0.99 \\
\hline \multirow{2}{*}{ Protonymph } & Female & -0.125 & 0.014 & 8.93 & 71.43 & 0.95 \\
\cline { 2 - 7 } Deutonymph & Male & -0.055 & 0.011 & 5.00 & 90.90 & 0.99 \\
\hline \multirow{2}{*}{ Immature } & Female & -0.171 & 0.017 & 10.06 & 58.82 & 0.95 \\
\cline { 2 - 7 } & Male & -0.084 & 0.014 & 6.00 & 71.43 & 0.94 \\
\hline \multirow{2}{*}{ Life cycle } & Female & -0.05 & 0.005 & 10.00 & 200.00 & 0.94 \\
\hline & Male & -0.035 & 0.004 & 8.75 & 250.00 & 0.98 \\
\hline
\end{tabular}

Table 3. Life-table parameters of Hemicheyletia congensis reared on Petrobia tritici at different temperatures

\begin{tabular}{|c|c|c|c|}
\hline Parameter & $20^{\circ} \mathrm{C}$ & $25^{\circ} \mathrm{C}$ & $30^{\circ} \mathrm{C}$ \\
\hline Mean generation time $\left(\mathrm{T}_{\mathrm{G}}\right)^{\mathrm{a}}$ & 31.82 & 25.05 & 17.31 \\
\hline Gross reproduction rate $(\mathrm{GRR})^{\mathrm{b}}$ & 45.54 & 76.56 & 59.27 \\
\hline Survival rate $\%$ & 75.0 & 90.0 & 80.0 \\
\hline $50 \%$ mortality & 43 & 35 & 26 \\
\hline Sex ratio (females/total) & 0.70 & 0.75 & 0.70 \\
\hline Net reproductive rate $\left(\mathrm{R}_{\mathrm{o}}\right)^{\mathrm{b}}$ & 33.07 & 62.84 & 45.19 \\
\hline Intrinsic rate of increase $\left(r_{m}\right)^{c}$ & 0.109 & 0.165 & 0.220 \\
\hline Finite rate of increase $(\lambda)$ & 1.11 & 1.17 & 1.24 \\
\hline Doubling generation (DT) ${ }^{\mathrm{a}}$ & 6.35 & 4.20 & 3.15 \\
\hline
\end{tabular}

${ }^{\mathrm{a}}$ Day, ${ }^{\mathrm{b}}$ per generation, ${ }^{\mathrm{c}}$ individuals/female/day

Predator's prey consumption:

The total number of prey consumed was variable according to difference of temperatures, (Table 4). Obtained results indicated that $H$. congensis females and males had highest predation capacity at $25^{\circ} \mathrm{C}$ as 419.3 for females and 299.7 for males during their life span. Number of prey consumed during predator total immatures averaged 50.0, 104.5 and 71.6 prey/female and 41.7, 104.2 and 62.1 prey/male when fed on tested temperatures, respectively. During adult longevity consumption was 156.3, 314.8 and 240.7 prey/female and $129.5,195.5$ and $131.5 \mathrm{prey} / \mathrm{male}$ on the same temperatures, respectively.

Means within rows followed by the same letter were not significantly different at the 5\% level.
The present study presented the biology and effects of temperature variability on the biological aspects, life table parameters, predation capacity of cheyletid mite, $H$. congensis on three temperatures 20, 25 and $30^{\circ} \mathrm{C}$ at $65 \%$ R.H under laboratory conditions when fed on $P$. tritici infesting wheat plants. Obtained results should the ability of using it in the control of the wheat crop mite pest from 20 to $30^{\circ} \mathrm{C}$ at with optimal at $25^{\circ} \mathrm{C}$.

Similar results were obtained by Mesbah et al. (2017) they studied biological aspects of Cheletomorpha lepidopterorum on the tetranychid brown wheat mite, P. latens at $20^{\circ} \mathrm{C}$ and $60 \%$ R.H under the laboratory. Mesbah and Omar (2014) reared Cheletogenes ornatus (Canestrini \& Fanzago) on eggs and immatures 
of Tenuipalpid mite, Raoiella indica Hirst at ( $35 \pm 2{ }^{\circ} \mathrm{C}$ and $50 \pm 5 \%$ R.H.). Mahagoub et al. (2017) studied the effect the acarid mite, Tyrophagous putrescentiae and the free living nematodes, Rhabditi scanica (Allegan) as food at 25 and $35^{\circ} \mathrm{C}$, and relative humidity $70 \% \mathrm{RH}$. on the biological aspects of $H$. congensis. Hassan et al. (2014) explained that $C$. ornatus
$(\mathrm{C} \& \mathrm{~F})$ reproduced on crawlers of scale insect, Hemberlisia lataniae (Signoret); immatures of tetranychid mite, Eutetranychus orientalis (Klein) and acarid mite, T. putrescentiae at 20 and $25 \pm 2{ }^{\circ} \mathrm{C}$ and $65 \pm 5 \%$ RH. Mesbah (2016) evaluated cheyletid mite, $C$. ornatus early release for overcoming Tetranychus urticae Koch on Soybean plants in Sharkia governorate.

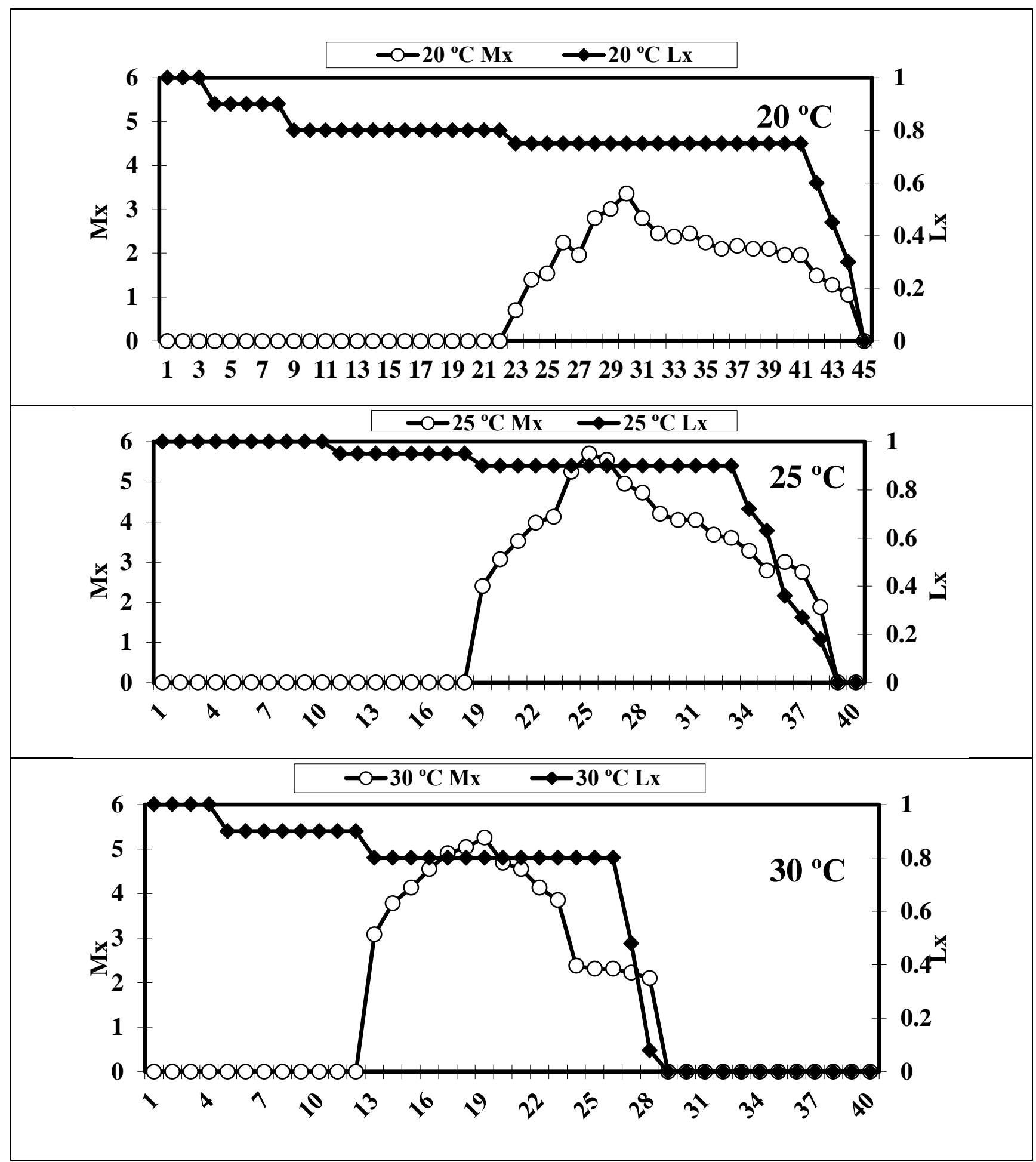

Figure 1. Age specific survivorship $\left(l_{\mathrm{x}}\right)$ and age-specific fecundity $\left(\mathrm{m}_{\mathrm{x}}\right)$ for Hemicheyletia congensis reared on Petrobia tritici at different temperatures at 20,25 and $30^{\circ} \mathrm{C}$. 
Table 4. Prey consumed (Mean \pm SD.) of predatory mite Hemicheyletia congensis per female and male reared on Petrobia tritici under laboratory conditions at different temperatures

\begin{tabular}{lccrccc}
\hline $\begin{array}{l}\text { Developmental } \\
\text { stages }\end{array}$ & $20{ }^{\circ} \mathrm{C}$ & $25^{\circ} \mathrm{C}$ & $30^{\circ} \mathrm{C}$ & $\begin{array}{c}\text { F- } \\
\text { value }\end{array}$ & $\begin{array}{c}\text { P- } \\
\text { value }\end{array}$ & $\begin{array}{c}\text { L.S.D } \\
\text { at }\end{array}$ \\
\hline Female & & & & & & \\
\hline Larva & $15.30 \pm 1.16 \mathrm{c}$ & $25.00 \pm 2.36 \mathrm{a}$ & $19.10 \pm 0.88 \mathrm{~b}$ & 93.48 & 0.0001 & 1.46 \\
\hline Protonymph & $17.20 \pm 1.03 \mathrm{c}$ & $36.50 \pm 2.42 \mathrm{a}$ & $23.90 \pm 1.10 \mathrm{~b}$ & 355.2 & 0.0001 & 1.50 \\
\hline Deutonymph & $17.50 \pm 2.80 \mathrm{c}$ & $43.00 \pm 3.50 \mathrm{a}$ & $28.60 \pm 1.26 \mathrm{~b}$ & 266.5 & 0.0001 & 2.46 \\
\hline Immature & $50.00 \pm 2.58 \mathrm{c}$ & $104.50 \pm 4.9 \mathrm{a}$ & $71.60 \pm 1.90 \mathrm{~b}$ & 645.8 & 0.0001 & 3.13 \\
\hline Preoviposition & $8.10 \pm 2.33 \mathrm{c}$ & $12.10 \pm 2.02 \mathrm{~b}$ & $14.30 \pm 2.45 \mathrm{a}$ & 19.07 & 0.0001 & 2.08 \\
\hline Oviposition & $139.50 \pm 4.5 \mathrm{c}$ & $291.5 \pm 38.9 \mathrm{a}$ & $214.2 \pm 10.4 \mathrm{~b}$ & 105.7 & 0.0001 & 21.45 \\
\hline Postoviposition & $8.70 \pm 0.95 \mathrm{~b}$ & $11.20 \pm 1.69 \mathrm{a}$ & $12.20 \pm 3.05 \mathrm{a}$ & 7.48 & 0.0002 & 1.91 \\
\hline Adult longevity & $156.30 \pm 4.8 \mathrm{c}$ & $314.8 \pm 38.8 \mathrm{a}$ & $240.7 \pm 12.1 \mathrm{~b}$ & 112.6 & 0.0001 & 21.68 \\
\hline Life span & $206.30 \pm 6.6 \mathrm{c}$ & $419.3 \pm 40.8 \mathrm{a}$ & $312.3 \pm 13.1 \mathrm{~b}$ & 181.03 & 0.0001 & 22.96 \\
\hline Male & & & & & & \\
\hline Larva & $11.60 \pm 0.97 \mathrm{c}$ & $20.00 \pm 2.36 \mathrm{a}$ & $15.10 \pm 0.74 \mathrm{~b}$ & 75.94 & 0.0001 & 1.40 \\
\hline Protonymph & $13.60 \pm 0.52 \mathrm{c}$ & $41.50 \pm 6.69 \mathrm{a}$ & $20.00 \pm 2.36 \mathrm{~b}$ & 126.8 & 0.0001 & 3.76 \\
\hline Deutonymph & $16.50 \pm 1.96 \mathrm{c}$ & $42.70 \pm 2.91 \mathrm{a}$ & $27.00 \pm 1.63 \mathrm{~b}$ & 348.8 & 0.0001 & 2.04 \\
\hline Immature & $41.70 \pm 1.57 \mathrm{c}$ & $104.20 \pm 8.7 \mathrm{a}$ & $62.10 \pm 3.28 \mathrm{~b}$ & 340.1 & 0.0001 & 5.01 \\
\hline Adult longevity & $129.50 \pm 3.7 \mathrm{~b}$ & $195.50 \pm 7.6 \mathrm{a}$ & $131.5 \pm 8.18 \mathrm{~b}$ & 305.0 & 0.0001 & 6.23 \\
\hline Life span & $171.20 \pm 4.5 \mathrm{c}$ & $299.7 \pm 10.7 \mathrm{a}$ & $193.60 \pm 9.6 \mathrm{~b}$ & 621.7 & 0.0001 & 7.98 \\
\hline \multicolumn{1}{c}{ Omar and }
\end{tabular}

Omar and Mesbah (2015) investigated

that Amblyseius. cydnodactylon (Shehata \&Zaher) may be a considerable value for controlling P.tritici in Egypt.

In conclusion, obtained results determined the possibility of using the tetranychid mite species $P$. tritici as fprey for the mass-rearing of cheyletid predator H. congensis. Complementary studies for that species, as other factors could influence the suitability of spider mite, $P$. tritici and $25^{\circ} \mathrm{C}$ as optimal temperature for integrated pest management.

\section{Acknowledgement}

The authoress wishes to express her thanks to Prof. Dr. Mohamed Abou-Setta for his valuable comments, revealing earlier copy of the manuscript and conducting revision for statistical analysis. Also, My deep gratitude to Dr. Ashraf El Halawany, Senior Researcher of Acarology at Plant Protection Research Institute, A.R.C., Dokki for his support, reviewing the manuscript, statistical analysis and helping me in mass rearing the prey, $P$. tritici.

Abou-Setta MM, Sorrell RW, Childers CC. 1986. Life 48 A BASIC computer program to calculate life table parameters for an insect or mite species. Florida Entomologist, 69(4): 690-697.

Birch LC. 1948. The intrinsic rate of natural increase of an insect population. Journal Animal Ecology, 17: 15-26.

Carrillo DF, Rodrigues JC, Pena JA. 2012. A review of the natural enemies of the red palm mite, Raoiella indica (Acari: Tenuipalpidae). Experimental and Applied Acarology, 57:347 -360.

El-Enany MA, Yousef MA, Abdel -Rahman SI. 1992. Effect of temperature on the biology of Cheletomorpha lepidopterorum (Shaw). Egyptian Journal of Agriculture Research,70: 741-751.

El-Naggar ME, Abd-Al-Aal ZE, El-Bashier ZM, Mesbah AE. 2006. Effect of temperature on the biology of predator mite, Cheletomorpha lepidopterorum (Shaw) Acari: Cheyletidae. Egyptian Journal of Agriculture Research, 84(2): 421-427.

Gerson U, Fain A, Smiley RL. 1999. Further observations on the Cheyletidae (Acari), with a key to different genera of the 
Cheyltinae and a list of all known species in the family. Bulletin do l' Institut. Rival des Science naturelles Belgigque (Entomology), 69: 35-68.

Hassan MF, El-Naggar ME, Mesbah AE, ElNahas RA. 2014. Biological aspects and life table parameters of Cheletogenes ornatus (Canestrini \& Fanzago) (Acari:Cheyletidae) when fed on different types of food and temperatures. Acarines, 8: 31-35.

Kandeel MMH, El-Naggar ME, Mohamed OMO. 2007. A new species of Petrobia Murray from wheat and other crop plants in Egypt (Acari:Tetranychidae). Egyptian Journal of Agriculture Research, 85: 885892.

Mahagoub MH, Yassin EMA, Khalil AM, Afify HA. 2017. Notes on biology of Cheletominus congensis (Cunliffe) when feed on different diets at different temperatures. Egyptian Academic Journal of Biological Sciences, 10: 97-105.

Mesbah AE. 2016. Efficiency of two predatory mites Amblyseius swirskii and Cheletogenes ornatus early release in controlling the two spotted spider mite, Tetranychus urticae Koch on Soybean plants in Sharkia Governorate. Journal of Plant Protection and Pathology, Mansoura University, 7:837-843.

Mesbah AE, Omar NA. 2014. Predator-prey preferences and life-table-parameters of Cheletogens ornatus (Canestrini \&Fanzago) to red palm mite Raoiella indica Hirst and date-scale-insect Parlatoria blanchardii (Targ.) (Acari: Cheyletidae: Tenuipalpidae). Acarines, 8: 19-23.

Mesbah AE, Tawfik AA, Abou El-Atta DA, Saleh FM. 2017. Effect of different prey on biological aspects, fecundity and life table parameters of the predatory mite, Cheletomorpha lepidopterorum Shaw (Acari:Actinidida:Cheyletidae). Journal of Plant Protection and Pathology, Mansoura University, 8: 21-25.

Negm MW, Mesbah AE. 2014. Review of the mite family Cheyletidae (Acari: Trombidiformes: Cheyletoidea) of Egypt. Internantional Journal of Acarolology, 40: 390-396.
Omar NA, Mesbah AE. 2015. The effect of temperature on development, fecundity and food consumption of Amblyseius cydnodactylon Shehata \& Zaher (Acari: Phytoseiidae). Egyptian Journal of Agriculture Research,93(1): 45-55.

Royer T. 2009. Brown wheat mite showing up in winter wheat. Pest E-alerts, Oklahoma State University Extension, 8(3):1-3.

SAS Institute. 2003. SAS Statistics and Graphics Guide, Release 9.1. SASInstitute, Cary, North Carolina, 27513, USA.

Shewry PR, Hey SJ. 2015. The contribution of wheat to human diet and health. Food and Energy Security, 4(3): 178-202.

Sun,W, Cui M, Xia L, Yu Q, Cao Y, Wu Y. 2020. Age-Stage, Two-Sex Life Tables of the predatory mite Cheyletus Malaccensis Oudemans at different temperatures. Insects Biological Control and Insect Pathology, 11:130- 181

Yassin EMA, Sallam GME, Ibrahim SA. 2008. Studies on the feeding, reproduction and development of Cheletomorpha lepidopterorum (Shaw) (Prostigmata: Cheyletidae) on various food sources. Integrated protection of stored products IOBC/wprs Bulletin, 40:53 - 62.

Zaher MA. 1986. Survey and Ecological Studies on Phytophagous,Predaceous and Soil Mites in Egypt. IIA:Predaceous and Nonphytophagous Mites (Nile Valley and Delta).Text. PL 480 Programme U.S.A., Project No. EGARS-30, Grant No. FG-EG-139, 567 pp.

Zaher MA, Yousef AE A, Kandil MM. 1981. Effect of food on the biology of Cheletogenes ornatus (C. \& F.) [Acari: Prostigmata: Cheyletidae]. Acarologia, 22; 361-366. 